\title{
ESTIMATING THE TIME OF ESTABLISHMENT OF THE CUTTHROAT TROUT (ONCORYNCHUS CLARKI LEWISI) POPUlation IN AVALANCHE LAKE, THROUGH ANALYSIS OF FOSSIL ZOOPLANKTON ASSEMblages in Profundal Sediments: Glacier NATional PARK
}

\author{
HERBERT E. WRIGHT, JR. \ DIRK VERSCHUREN \\ LIMNOLOGICAL RESEARCH CENTER $\bullet$ DEPARTMENT OF GEOLOGY \& GEOPHYSICS \\ UNIVERSITY OF MINNESOTA $\bullet$ MINNEAPOLIS
}

\section{$\checkmark \quad$ EXEUTIVE SUMMARY}

Surviving populations of native cutthroat trout (Oncorynchus clarki lewisi) in isolated lakes of Glacier National Park are being assigned a potentially important role in a recovery program of cutthroat trout fishery in the Lake McDonald basin. One population of native trout inhabits Avalance Lake; yet its indigenous nature is questioned, because of the absence of other fish species that normally occur in association with the trout, and because the creek giving access to Avalanche Lake from Lake McDonald is considered too precipitous for naturally dispersing fish.

This study aims to find out whether the trout population in Avalanche Lake was established following a deliberate but unrecorded introduction sometime during the last century, or much earlier through successful natural immigration. Evidence is to be derived from examination of fossil zooplankton assemblages contained in the lake's profundal bottom sediments. The approach is based on the idea that introduction of planktivorous fish to a fishless lake must have caused significant changes in the zooplankton community. Visual, size-selective predation by planktivorous fish typically results in preferential removal of larger prey types and/or of prey that tend to stay in the upper water column during daytime. There are two groups of zooplankters in Glacier National Park lakes whose populations are likely to be affected, and whose buried remains preserve well enough to trace these changes in the sedimentary record: the limnetic cladoceran Daphnia, and the planktonic larvae of Chaoborus, a dipterous insect. In Daphnia, changes associated with fish introduction may include a shift to smaller body-size in resident species or a replacement altogether of large species by smaller ones. In Chaoborus, species that lack the habit of diurnal vertical migration are rapidly eliminated, and may then be replaced by congeners that do migrate.

Analysis of fossil zooplankton assemblages in a $210 \mathrm{~Pb}$-dated sediment profile may be able to establish if species replacement and/or a directional shift toward smaller individuals has occurred in the recent past or not. If change has occurred, then deliberate introduction of trout into a formerly fishless Avalanche Lake would be the likely cause. If no 
such change can be detected, suggesting that the food web structure has remained stable for at least about 150 years, then the proposition that Avalanche Lake cutthroat trout are indigenous would gain crednece.

Two short piston cores were retrieved from the profundal bottom of Avalanche Lake, at a neardeepest locality in $19.8 \mathrm{~m}$ of water. Special attention was paid not to disturb the sediment/water interface. In upright position and with the pistons in place, the cores were carried down along Avalanche Creek, then brought to the bungalow at Apgar by car. There they were extruded, sectioned in $1 \mathrm{~cm}$ thick slices and transferred to separate airtight plastic (Wirl-Pack) bags for transport.

On five single-day outings, seven other lakes in Glacier National Park were visited (Table 1). Lakes were selected on the basis of accessibility and, ideally, a general similarity to Avalanche Lake in hydrogeological setting. Four of these lakes (Fish, Lower Snyder, Trout and Hidden Lakes) contain indigenous or introduced populations of cutthroat trout; the three others (Upper Snyder Lake, Hidden Pond and Babbe Lake ) supposedly do not support fish. Upper-Snyder Lake (at $1699 \mathrm{~m}$ ) and Hidden Pond (1944 m) probably are too shallow for resident fish populations to survive winter freeze-over. Babbe Lake (at least $12.5 \mathrm{~m}$ deep) lies in the midst of forest and has no permanent outlet to nearby Bow Creek, which connects with the Kintla drainage.

At corresponding near-deepest localities in each of the lakes, surface mud was collected by means of a Hongve gravity corer. Composition of recent assemblages of zooplankton remains in the surface

Table 1. Locality information for the reference collections of modern zooplankton and corresponding fossil assemblages in recently deposited sediments, from selected lakes and ponds in Glacier NP. Altitudes in meter a.s.1., based on 1:25,000 topographic maps of the Mt Cannon, Logan Pass, Lake McDonald East, Camas Ridge East, and Kintla Peak Quadrangles; locality depth and type (near-deepest ND and littoral LT) refer to the Hongve sediment samples.

\begin{tabular}{||l|l|l|l|l|l|l||}
\hline Date & Name & Code & Alt & Drainage & Depth & Type \\
\hline 091891 & Avalanche Lake & AVAL & 1191 & $\begin{array}{l}\text { MFFlathead- } \\
\text { McDonald }\end{array}$ & 19.80 & ND \\
\hline 092091 & Fish Lake & FISH & 1265 & $\begin{array}{l}\text { MFFlathead- } \\
\text { McDonald }\end{array}$ & 7.20 & ND \\
\hline 092291 & Lower Snyder Lake & LSNY & 1585 & $\begin{array}{l}\text { MFFlathead- } \\
\text { McDonald }\end{array}$ & 0.55 & LT \\
\hline 092291 & Upper Snyder Lake & USNY & 1699 & $\begin{array}{l}\text { MFFlathead- } \\
\text { McDonald }\end{array}$ & 2.00 & ND \\
\hline 092391 & Trout Lake & TROU & 1190 & $\begin{array}{l}\text { NFFlathead- } \\
\text { Camas }\end{array}$ & 20.10 & ND \\
\hline 092491 & Hidden Lake & HIDL & 1944 & $\begin{array}{l}\text { MFFlathead- } \\
\text { McDonald }\end{array}$ & 20.10 & ND \\
\hline 092491 & pond, NW Hidden Lake & HIDP & 1944 & $\begin{array}{l}\text { MFFlathead- } \\
\text { McDonald }\end{array}$ & 1.55 & ND \\
\hline 092591 & 'Babbe Lake' (unnamed) & BABB & 1309 & NFFlathead-Kintla & 12.55 & ND \\
\hline
\end{tabular}


mud samples will serve as reference for evaluation of paleoassemblages in the Avalanche Lake core. At the same limnetic localities, modern late-summer zooplankton was sampled qualitatively with a 85 um mesh plankton-net. The net was lowered to nearbottom and then hauled through the water column, to obtain an integrated sample of hypo- and epilimnetic zooplankton. The net was then hauled through the upper water column only, as defined by the water depth at which the net became invisible; this sample is considered to represent the ( epilimnetic) zooplankton, which is most vulnerable to visual predation by fish.

\section{ACCOMPLISHMENTS TO DATE}

1. One core (Core 1: $74 \mathrm{~cm}$; Figure 1) is used for dating purposes, and for sediment and macrofossil analyses. The other core (Core 2: $60 \mathrm{~cm}$ ) is kept intact for future reference. Basic sediment composition and water content (Figure $2 \mathrm{a}, \mathrm{b}$ ) were determined by the loss-on-ignition method. The close-interval profile of water content will be employed to calculate instantaneous sedimentation rates, a detailed assessment of which is necessary to establish a correct $210 \mathrm{~Pb}$-chronology.

2. Study of modern zooplankton in the set of reference lakes and ponds (Table 2). Copepods dominate the late-summer zooplankton community in the majority of lakes sampled. In Trout Lake, Hidden Lake and Pond, and Babbe Lake, the dominant copepods are calanoids; in Avalanche Lake, the dominant copepod is a cyclopoid. Copepods cannot be employed for the purpose of this study, because their remains do not survive long in the sediment record. Therefore, specific identification of all the copepods present is not considered crucial here. Calanoid copepods identified include Diaptomus cf. oregonensis (Trout Lake), Diaptomus arcticus (one of at least two species in Hidden Lake), and Arctodiaptomus arapahoensis (Hidden Pond); cyclopoid copepods include Tropocyclops prasinus (Fish Lake) and Mesocyclops cf. tenuis (Babbe Lake). In theory, comparison of modern zooplankton in lakes with and without fish should already reveal the differences we would expect to find in the fossil record of Avalanche Lake. However, a clear distinction between these two categories of lakes, as point-sampled in late-summer, is not apparent (Table 2). Major differences among lakes in depth and trophic level might be two of the more important factors involved. Still, the largest Daphnia were found in Upper Snyder Lake and Hidden Pond, which are both fishless; and the presence in fishless Babbe Lake of the non-migrating Chaoborus americanus, which is highly susceptible to fish predation, is suggestive indeed.

\section{- $\quad$ FURTHER WORK PLANNING}

1. Measurement of $210 \mathrm{~Pb}$-activity at selected levels of core 1 , to construct a chronology of events.

2. Establishment of the relationship between length of the postabdominal claw and body length in the two species of Daphnia found in the modern samples. Besides ephippia, postabdominal claws are the only diagnostic parts of a Daphnia - body that preserve well enough to be recovered in quantity from sediment samples.

3. Examiniation of subfossil zooplankton assemblages in the Hongve samples of surface sediment. This involves (i) identification and count of Chaoborus mandibles, Daphnia ephippia, and Daphnia postabdominal claws: (ii) for each species of Daphnia present, measurement of postabdominal claws as a proxy for body size; and (iii) characterization of paleoassemblages (relative abundance of composing species and size range of Daphnia) for lakes with and without fish.

4. In a similar way as under (3), examination of fossil assemblages in the last century's sedimentary record of Avalanche Lake.

5. Statistical analysis of the count and measurement data to detect and quantify changes over time. 


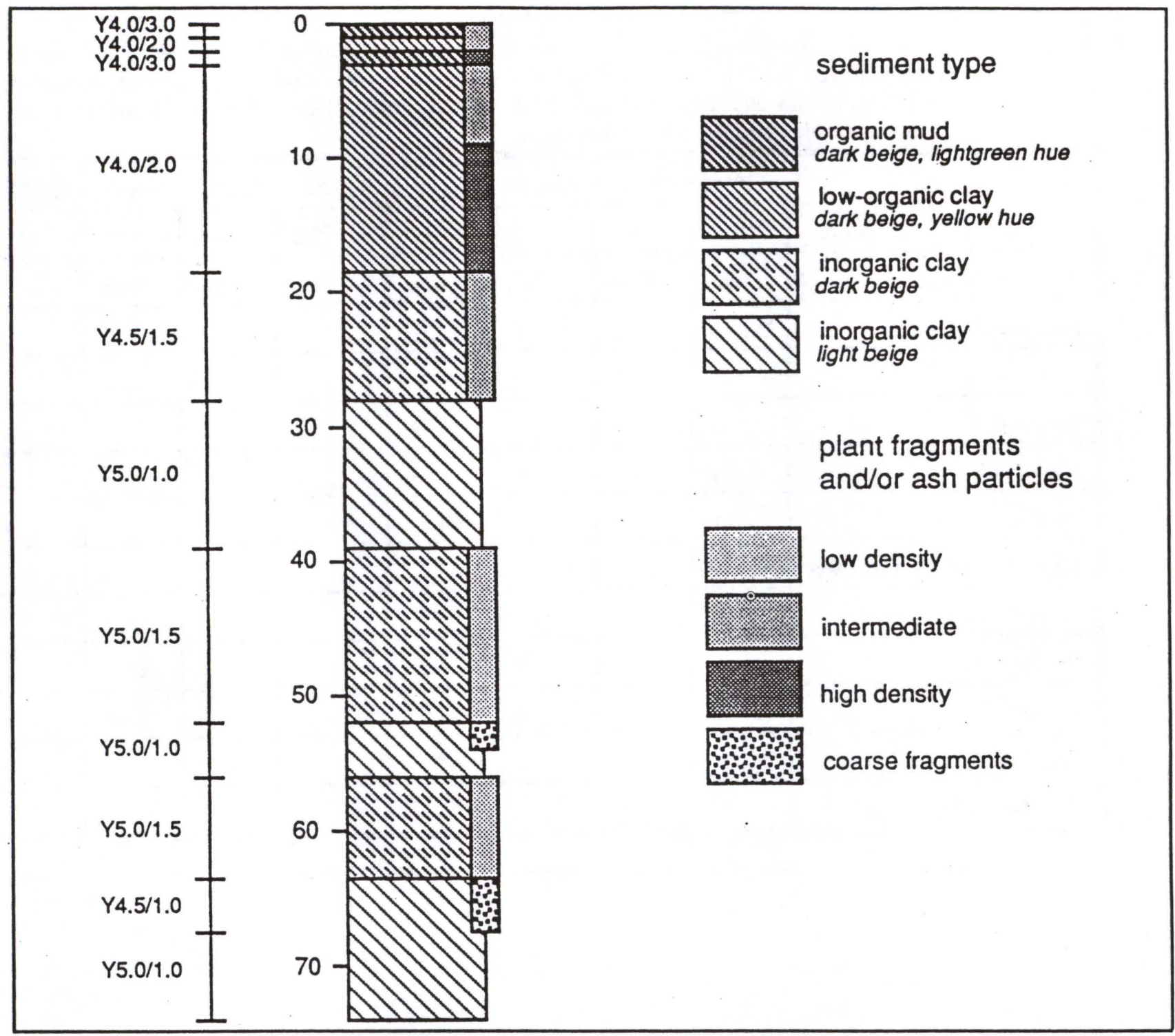

Figure 1. Stratigraphy of Avalanche Lake Core 1, collected at a near-deepest locality in $19.80 \mathrm{~m}$ waterdepth. Color codes on left follow Munsell (1915: Atlas of the Munsell color system).

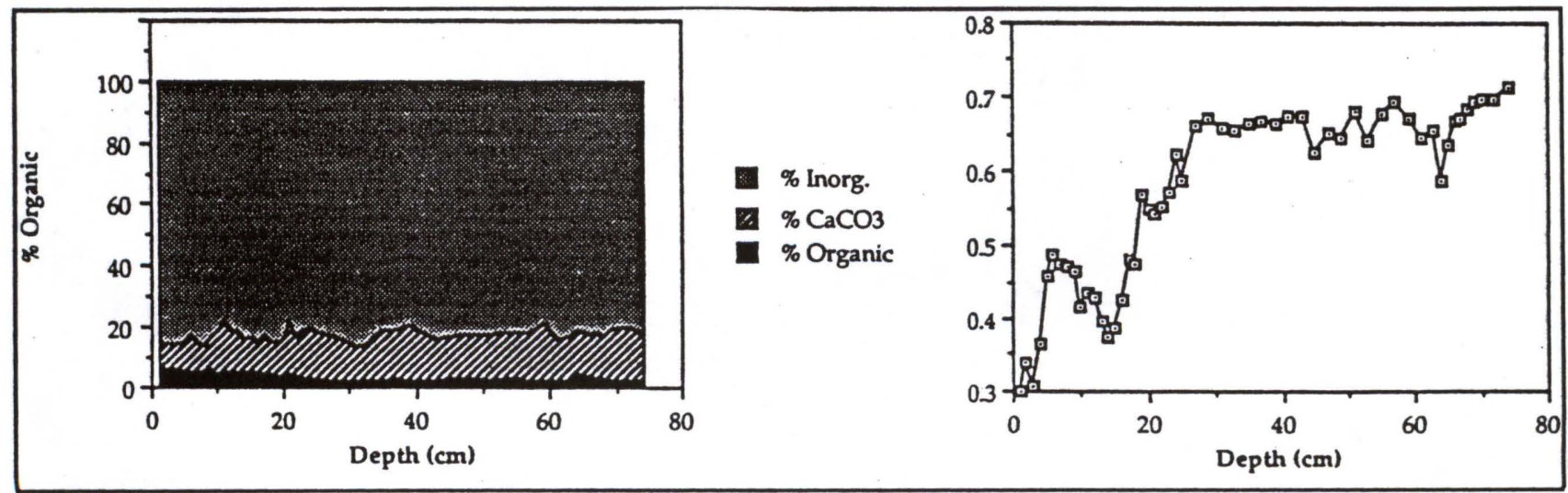

Figure 2. Sediment composition (a), and dry weight/wet weight ratio (b) along the profile of Core 1. 
Table 2. Composition of late-summer zooplankton in selected lakes and ponds of Glacier NP, September 1991; taxa in boldface can be found and recognized in fossil assemblages. $+=$ present, $c=$ common, $a=$ abundant; epilimnetic water temperature, for central (limnetic) or near-shore (littoral) locations, in degrees centigrade; for lake codes see Table 1.

\begin{tabular}{||l|r|r|r|r|r|r|r|r||}
\hline & AVAL & FISH & LSNY & USNY & TROU & HIDL & HIDP & BABB \\
\hline Surface water temperature & 10.1 & 15.7 & 8.3 & 8.1 & 13.5 & 9.5 & 10.6 & 13.5 \\
\hline Sampling location & limn & limn & litt & limn & limn & limn & limn & limn \\
\hline Fish presence & $\mathrm{Y}$ & $\mathrm{Y}$ & $\mathrm{Y}$ & $\mathrm{N}$ & $\mathrm{Y}$ & $\mathrm{Y}$ & $\mathrm{N}$ & $\mathrm{N}$ \\
\hline & & & & & & & & \\
\hline Calanoids & + & $\mathrm{c}$ & & + & $\mathrm{a}$ & $\mathrm{a}$ & $\mathrm{a}$ & $\mathrm{a}$ \\
\hline Cyclopoids & $\mathrm{a}$ & + & + & + & $\mathrm{a}$ & & $\mathrm{a}$ & $\mathrm{a}$ \\
\hline Daphnia rosea & + & $\mathrm{c}$ & + & $\mathrm{c}$ & $\mathrm{c}$ & & & + \\
\hline Daphnia middendorffiana & + & & + & & & & $\mathrm{c}$ & \\
\hline Holopedium gibberum & & $\mathrm{c}$ & & & & & & \\
\hline Chydorus sp. & & & + & & & & + & + \\
\hline Hydracarina & & + & & & & & & \\
\hline Chaoborus americanus & & & & & & & & + \\
\hline Chaoborus flavicans & & + & & & & & & \\
\hline
\end{tabular}

